
Reprintod for the Author from the BRITISI MEDICAL JOURNAL, Januaxy 20th, 1894.

\title{
ON THE VALUE OF THE BACTERIOLOGICAL DIAGNOSIS OF ASIATIC CHOLERA.
}

\author{
BY SHERIDAN DELÉPINE, M.B.EDIN., \\ Professor of Pathology, Owens College, Manchester.
}

"BACTERIOLOGICALLY indistinguishable from Asiatic cholera" is an expression which, to some, will undoubtedly convey a feeling of doubt concerning the value of the bacteriological diagnosis, whilst for those who believe that the spirillum choleræ Asiaticæ is the cause of the disease, the same expression leaves absolutely no doubt as to the nature of the ease; the presence of the comma bacillus "eonstituting an infallible diagnostic sign of the existence of the disease." The diagnosis of cholera is by all acknowledged to be based on evidences of four kinds (1) clinical, (2) anatomieal, (3) epidemiological, (4) bacteriologieal.

\section{Cinical EVIDENCE.}

The clinical diagnosis presents serious difficulties, for $(A)$ the symptoms, even of undoubted cases, vary much in intensity and in sequence. (B) Other illnesses may elosely simulate Asiatic cliolera: among them may be mentioned eholera nostras (English cholera, summer diarrhoa, infantile diarrhoa), perforation of the stomach and bowel, cold stage of remittent fever, poisoning by certain organic poisons (muscarin, croton oil, food poisoning), poisoning by eertain inorganic poisons (arsenic, nitrites-the latter according to Emmerich and Tsuboi). ${ }^{2}$. All the essential symptoms of Asiatie eholera-namely, (1) diarrh oea witl rice-water stools, (2) vomiting, (3) cramps, (4) suppression of bile and urine, (5) pinehed expression and lividity, (6) extrem prostration and eollapse, (7) coldness of surface but not of rectum, (8) reaction or fever in cases not dying in the stage of collapse, (9) deatl in a certain proportion of cases-may be observed in severe cases of cholera nostras, in which, however, suppression of urine and bilc are seldom seen. Unfortunately for the diagnosis, supcholera. This difficulty is so great, that Koch ${ }^{3}$ himself lias said that when an epidemic of eholera lias reached its acme, cases of acute diarrlıea, witlı vomiting and cramps, may bc considercd as choleraie without bacteriological analysis. (c) 'The difficulty is still further increased by the fact that some cases of alleged cholera, as diagnosed by the bacteriological metliod, sliow absolutely no symptoms. 


\section{ANatonical EVIDHNCE.}

The anatomical diagnosis of cholera is still more difficult than the clinical. Typical lesions of the intestine, and even typical stools are found only in a certain proportion of cases. $^{*}$

\section{EPIDAmiological EVIDENCE.}

The epidemiological notion must evidently be combined with the clinical and the anatomical diagnosis, since it is only the occurrence of cases which points to the existence of an epidemic.

It is well known that in the absence of any evidence of the importation of Asiatic cholera many cases, which in time of epidemic would be attributed to malignant cholera, are called cases of summer or English cholera. When an epidemic is raging, on the contrary, such cases would be described as examples of epidemic cholera (see Koch's statement above).

That this is a source of great confusion is shown by certain occurrences. There have been epidemics of choleraic disease in which the evidence of importation from Asia or from an infected country has been doubtful; this was the case with the Paris epidemic in 1892; the absence of evidence of importation led the authorities at first to give the name of diarrhée choleriforme to these attacks; yet a bacteriological examination of several of these cases proved the presence of the cholera spirillum (Netter, Metchnikoff').

The difficulties in this respect are considerably increased by the occurrence of local outbreaks undoubtedly connected with the supply of impure water-London, 1866 ; Marseilles, 1884, 1892; Paris, 1892; Hamburg, 1892; for these are capable of more than one interpretation. Moreover, cases, apparently sporadic, scem to have increased of late years, since the bacteriological diagnosis has come into use.

From what precedes it is evident that before the bacterial metlod was introduced the diagnosis of cholera was basea on a certain combination of cvidences clinical, epidemiological, and to a certain extent anatomical; and that these were not always conclusive.

\section{BACTERIOLOGicAL EVIDENCE.}

The bacteriological diagnosis is, according to Koch's latest publications, ${ }^{\bar{D}}$ to be obtained by means of the following tests:

1. Mieroseopieal examination of the freal matter stained with a dilute solution of earbolised fuchsin.

2. Cultivation in salted, peptonsed water, at $37^{\circ} \mathrm{C}$.

3. Cultivation on agar at $37^{\circ} \mathrm{C}$.

4. Gelatine plate eultivation at $22^{\circ} \mathrm{C}$.

5. Testing for the presenee of indol and nitrites in pure eultivations in

peptonised water (elholera red). on agar in a guinea-pig weigling from 300 to 350 grammes.

But Koch justly remarks that several of these methods have a limited value in themselves. Thus the simplo microscopical examination is only available in 50 per cent. of the cases, cven in the hands of the most experienced observers.

The cultivations on agar are used chiefly for the purpose of getting hacilli for peritoneal injeetions, and the plate 
cultures for the purpose of separating the bacilli (for the rate of liquefaction has had to be abandoned as a diagnostic test).

When morphologically typical spirilla have been found to be present in the intestine of a patient, the only two tests which may be relied upon are (A) the indol-nitrous reaction (cholera red), (B) the virulence of the cultivations on agar to guinea-pigs; and the cliolera-red reaction seems to be the more important of the two, for Koch has said, "None of the curved bacteria known until now does produce at the same time, when cultivated, indol and nitrous acid, and gives the characteristic reactions of cholera red." ${ }^{\circ}$ So great is Koch's confidence in the bacteriological diagnosis based on these tests that he considers men apparently healthy, in the solid stools of whom cholera bacilli have been found, as genuine cases of cholera. Such persons, he avers, have always been exposed to the influence of infection.

Unfortunately the comma bacilli are not present or, at any rate, easy to demonstrate in cases where reaction has set in, and Koch is also of opinion that in many cases where observer's have failed to discover the presence of the bacillus this was the result of inexperience on their part, therefore he says, "The absence or non-discovery of the bacilli in a suspected case does not always prove that the case is not one of cholera."

It is evident from what precedes that the bacteriological diagnosis is the only one for which infallibility is claimed. All patients, in the intestine of whom the comma bacillus is found, are to be considered cases of Asiatic cholera. On the other hand, we have seen that the only feature distinguishing malignant cholera from certain diseases giving rise to the same symptoms is its epidemic character. If it were proved that the spirilla found in cases of true cholera were found commonly in a district in the absence of an epidemic or of any evidence of infection, then, however constant their presence might be in cases of true epidemic cholera, one would be inclined to doubt their value as absolutely positive proof of the existence of the diseasc. On the other hand, if it were found that the spirillum is present in a district only when there has been a distinct evidence of direct or indirect contamination, with products of undoubted Asiatic origin, the value of the bacteriological diagnosis would be much increased.

(The assumption that the disease has become endemic of late in many countries, and that the spirillum is now to be found permanently in many districts, would not make clearer to us the origin of the great pandemics, and would considerably alter the character of the question of differential diagnosis between eholera nostras and cholera Asiatica.)

The following observations have, I think, an important bearing on this subject:

I will first mention the result of observations in Manchester. At the time when there was a possibility of the town becoming affected with cholera Dr. Tatham watelied for cascs cxhibiting suspicious symptoms, and found that in the second half of the month of September 4 paticnts were taken ill with choleraic symptoms. Of tliese, 3 died, 1 recovered. In two cascs there secmed to have been no evidence of infection. (This is a part of the subject which will be dealt with by Dr. Tatliam elsewlicre.) 
These cascs were followed by no other cases. In one of the fatal cases no comma bacillus could bc found; in that case the characters of the stools and of the intestine did not suggest in the least the existence of cliolern. In the two other fatal cases and in the one that recovered the comma bacillus was found without any difficulty. In the first case that occurred in Mancliester, in order to make absolutely certain that the results obtained by me would be comparable with those obtained by 10r. Klein, I sent him a spccimen of the the material obtained from the intestine, and he most kindly examined it, and I lad the satisfaction to find that $\mathrm{Dr}$. Klein in London and myself in Manchester had obtained independently absolutcly similar results, that is, we had obtained from that case spirilla in shape, size, and cultures, having all the characters of eholera bacilli, and giving the cholera red very well. In addition I found that small doses of pure cultivations of these spirilla on agar were very virulent to guinea-pigs. In the other two cases I found even more easily than in the first that comma bacilli were very abundant.

The characters of the organs were as follow:

In the first fatal case. Jejunum: Slightly congested; contents pale yellow, pappy, offensive freal smell. Ileum: Mucous and selous coats generally congested, but more specially so in patches; Peyer's patches indistimet; no licemorrhages; contents very thick, mucous, very adhesive, partly yellow, partly bright green, containiug a few whitish flakes.

Microscopical examination of the whitish flakes: Columnar epithelial cells abundant, large thick and long bacilli abundant, short straight or slightly curved bacilli abundant, micrococci abundant, some large toruloid organisms; curved bacilli having the characters of comma bacilli, but nowhere grouped typically.

The lungs were deeply congested and contained hæmorrhagic blocks, specially under the pleura. The liver was dark and congested. The kidueys showed typical cloudy swelling of the cortex, with small areas of congestion under the capsule. Intense congestion of the medulla (cholera kidney, so-called).

In the secoud fatal case the ileum showed hardly any change, except slight congestion of the serous coat. The contents were very thin, pale greyish brown, almost colourless, contaiuing whitish shreds and clear boiled-sago-like masses of mucus. The smell was slightly fæcal.

Micloscopically the contents were much poorer in cells and microorganisms than in the first case. The comma-shaped bacilli were also present, but uowhere iu typical groups.

The stools of the patient that recovered were thin, pulpy, pale greyish yellow in colour, and containing wlitish curdy masses or flakes; they had a distinct frecal smell.

Microscopically the whitish shreds contained a very few indistinct epithelial cells; a large amount of granular debris; long thin bacilli; sliort bacilli, which were abundant; streptococci; curved bacilli, resembling the comma bacillus, but nowhere forming typical groups.

Cultivation in this and in the other cases proved the presence of a large number of comma bacilli, indistinguishable from the cholera bacillus in shape, mode of growth, and chemical reactious. The bacterium coli coinmune was also found to be abundant.

The most interesting featurc I noticed in connection with the spirilla obtained from one case was that by proper selection of colonies on the gelatine plate it was possible to obtain sports of the organism liquefying gelatine at various rates. I was able to maintain these eultural differences tlirough several generations, but I cannot say yet whether they indicatc the existence of permanent varieties. They tend to prove, however, that the rigid monomorphism, attributed at one time to the spirillum eholeræ, was in great part due to judicious selection of specimens and to the production of almost invariable external circumstances.

$\Lambda s$ is well known, Cumningliam ${ }^{7}$ and Kilein have demonstrated the existenee of a large number of varieties of spirilia 
in choleraic dejecta. Cumningham's observations have not, perliaps, received yet the attention which they deserve.

Theobservations of Nicolle and Morax ${ }^{8}$ are perhaps not so well known. These obscrvers found that the comma bacilli obtained from various sources did not only show differences of size and sliape, but that some had four cilia or flagella (Massaowah, Calcutta, Paris, 1884), some had only one cilium (Slianghai, Hamburg, Paris, 1892; Angers, 1892), and in one instance it was impossible to demonstrate the existence of any cilium (Indian spirillum coming from Dr. Koch's laboratory). It is interesting to note that the vibrios of Finkler and Prior, Deneke, Gamaleïa, and those found by Blachstein and Sanarelli in water have all only one cilium, like the second group of cholera vibrios mentioned above. Dr. Richmond, working in my laboratory, has not been able to demonstrate more than one cilium in any of the spirilla I have isolated from the Manchester cases. It must be remembered that the cholera red reaction is a test important only in connection with spirilla isolated from the contents of the human intestine. The vibrio Metchnikovi gives the reaction and is pathogenic to guinea-pigs. ${ }^{9}$ It is even possible for the Finkler's spirillum to acquire this property (Bujwid). ${ }^{10}$ These two facts I have been able to confirm.

Quite recently, Blachstein ${ }^{11}$ and Sanarelli, ${ }^{12}$ Neisser, ${ }^{13}$ have described spirilla in water which are pathogenic to guineapigs, and give the cholera red reaction. Sanarelli's observations seem to be most complete, and are extremely interesting. His conclusions may be summed up as follows:

1. It is always possible to obtain from water contaminated with sewage spirilla having all the morphological, cultural, chemical, and pathogenic characters considered by Kocl as diagnostic of the cholera spirillum. (Sanarelli obtained pathogenic spirilla from four different sources.)

2. The pathogenic water spirilla do not long retain their pathogenic properties, and tley also lose the power of re-
ducing nitrates.

3. It is possible to find in water spirilla morphologically similar to the cholera spirillum, but not pathogenic to tlie same extent; these are probably derived from the pathogenic spirilla found in sewage. (Sanarelli found spirilla in water from thirty-two different sources; four of these spirilla were the pathogenic ones alluded to above.)

4. The constant presence of pathogenic spirilla in sewage seems to indicate that they are derived from intestinal
dejecta.

5. The close resemblance of the spirilla obtained from choleraic stools and of those found in water seems to indicate
a common origin.

Metchnikoff ${ }^{14}$ has found comma bacillio/I the stools of a healthy person in the absence of any nolera epidemic. Rumpel ${ }^{15}$ had made similar observations. Koch himself, in
various places, admits the possibility of the presence of cliolcra bacilli in the atools of person: apparently healthy, but insists upon the neccssity of their having been exposed cholera. Lesage and Macaigne 10 have written a very interesting
paper, giving the rcsults of a bact riological examination of
198 cascs of cholcra 198 cascs of cholcra. In these cascs tliey found the bacillus virgula abundant in 20 , moder,ctely abundant in 107, in 
small numbers and difficult to find in 24, and absent in 45 . In the 45 cases in which no comma bacillus was found, the with staphyloco found alone in 15 ; associated in 30 .

Protective inoculation might be said to have some bearing on the question of diagnosis, but the evidence obtained by the work of Ferrán, Gamaleia, Haffkine, Klemperer, Klcin, Metchnikoff, Pawlowsky, and Buchstab, etc., is of a nature which does not encourage reliance on such a method of diagnosis at the present time.

\section{General Conclusions.}

Although I am fully aware of the objections which Koch might offer, and has indeed offered, to some of the observations related above, it seems to me that the following conclusions can hardly be avoided:-

1. It is as yet impossible to speak dogmatically of the infallibility of the bacteriological diagnosis of cholera Asiatica.

2. All the more recent observations point to the importance of the contamination of water and soil with dejecta as a cause of outbreaks of cholera similar to Indian cholera.

3. These recent observations undoubtedly lend much support to the localistic views of Cunningham and of Pettenkofer, though in their details these views may have to be modified.

NoTE.-It is evident that until it is possible to speak more positively, the bacteriological examination will have to be conducted with even more care than it has been hitherto, as only in this way will it be possible to remove all the doubts that remain.

\section{REFERENCES.}

1 Koch, Semaine Médicate, May 31st, 1893, p. 265. ${ }^{2}$ Mfcdical Chronicle, 1893, xviii, p. 323. Regarding this see also Kleinperer, Mcdicat Chronicle, xix, p. $37 .{ }^{3}$ Loc. cit. ${ }^{4} \mathrm{~K}$ och, The Etiology of Chotera, Nicroparasites in Disease, New Sydenham Society, p. 329 . '5eitschrift für Hygiene und Intcctrons-Krankheiten, vol. xiv, No.2, 1893; Semaine Nledicate, May, 1893, p. 268; Practitioner, 1893, vol. 1i, p. 471; BRITISH MEDICAL JOURNAL, June 17th, 1893. ${ }^{6}$ Semaine Médicale, 1893, p. 267. 7 Scientific Memoirs by the Medical Officer, etc., Catcutta, 1891. 8 Annates de 'Institut Pasteur, 1893, p. 554. ${ }^{9}$ Annates de l'Institut Pasteur, 1893, p. 562. 10 Zeitschr. f. Hyy. 1887; Annates dc l'Institut Pasteur, 1888, pp. 30-45; regarding the cholera red reaction, see Jadassolnn, ibid, 1888, p. 44. 11 Annates de l'Institut Pasteur, October, 1893, p. 689. 12 Toid., p. 693. 13 Hygicnische Rundschau, August, 1893. ${ }^{14}$ Annates de l'Institut Pasteur, 1893, p. 562. 15 Deut. med. Woch., 1893, p. 160. ${ }^{16}$ Annales de t'Institut Pcsteur, January 25th, 1893, p. 18. 
